Review article

Section: Food Quality and Functionality

\title{
Pigmented Maize (Zea mays L.) Contains Anthocyanins with Potential Therapeutic Action Against Oxidative Stress - A Review
}

\author{
Jesús Miguel Magaña-Cerino ${ }^{1}$, Héctor Arturo Peniche-Pavía ${ }^{2}$, Axel Tiessen ${ }^{2,3}$, Carmen Magdalena Gurrola-Díaz ${ }^{1 *}$ \\ 'Instituto de Investigación en Enfermedades Crónico Degenerativas, Instituto Transdisciplinar de Investigación e Innovación \\ en Salud, Departamento de Biología Molecular y Genómica, Centro Universitario de Ciencias de la Salud, \\ Universidad de Guadalajara, C. Sierra Mojada 950, Col. Independencia, C. P. 44350, Guadalajara, Jalisco, México \\ ${ }^{2}$ Departamento de Ingeniería Genética, Centro de Investigación y de Estudios Avanzados del Instituto Politécnico Nacional \\ Unidad Irapuato, Libramiento Norte Km. 9.6, C. P. 36824, Irapuato Guanajuato, México \\ ${ }^{3}$ Laboratorio Nacional PlanTECC, Libramiento Norte Km 9.6, C. P. 36824 Irapuato, Guanajuato, México
}

Key words: Zea mays L., anthocyanins, oxidative stress, antioxidant, in vivo and in vitro effect

Different maize (Zea mays L.) varieties have been used for thousands of years as a healthy food source in Mesoamerica including pigmented maize. Maize ingestion could contribute to the reduction in the rate of non-communicable diseases and, in turn, to its function as an adjuvant in their management. These diseases are mainly associated with oxidative stress, which is characterized by a redox cell imbalance produced due to pro-oxidant molecules accumulation, inducing irreversible damages. Although the endogenous antioxidant defense system is efficient, exogenous antioxidants are necessary to help to prevent this damage. Bioactive compounds, like anthocyanins, contained in dietary plants exert a major activity against oxidative stress. Could the maize anthocyanins play a curative, preventive or complementary role in the treatment of chronic diseases? Here, we describe the occurrence of anthocyanins from pigmented maize and their chemical structures. Furthermore, the biosynthesis, bioavailability, and stability are also summarized. Finally, many in vitro and in vivo studies of maize anthocyanins are discussed that demonstrated their nutraceutical potential, antioxidant capacity, and other biological effects. Given the importance of the biological properties of maize anthocyanins, it is necessary to understand the current knowledge and propose further research or clinical studies which allows us to better elucidate the biological mechanism of maize anthocyanins derivatives of several varieties and processes of cooking and combination with other ingredients to enhance their nutritional and health benefits.

\section{INTRODUCTION}

Oxidative stress is a condition that begins when the redox balance of living organisms is altered by an excessive formation of radical molecules, which exceeds the endogenous antioxidant capacity [Lobo et al., 2010]. Usually, the electron transport chains in the mitochondria utilize oxygen to convert nutrients into adenosine triphosphate (ATP) and through this process generate radicals, which are used to carry out cellular signaling processes. However, various environmental, physi$\mathrm{cal}$, and chemical factors can cause the excessive generation of these radicals, resulting in the chemical imbalance of biomolecules and cellular stress [McCord, 2000].

The main feature of this condition is an increase in free radicals and reactive species such as hydrogen peroxide $\left(\mathrm{H}_{2} \mathrm{O}_{2}\right)$, superoxide $\left(\mathrm{O}_{2}^{-}\right)$, hydroxyl radical $\left(\mathrm{HO}^{-}\right)$, singlet oxygen $\left({ }^{1} \mathrm{O}_{2}\right)$, alkoxy radical (RO), and peroxyl radical (ROO'). These compounds cause necrosis, apoptosis, damage, and cell death due to modification in the structure and function of macromolecules such as lipids, proteins (in biological

\footnotetext{
* Corresponding Author: Tel. +52 (33) 10585200 Ext. 33930

E-mail: carmenhpv@yahoo.de (C.M. Gurrola-Díaz)
}

membranes and tissues), and deoxyribonucleic acid (DNA) [Birben et al., 2012].

Although the endogenous antioxidant defense system is efficient, sometimes it is overwhelmed and needs exogenous antioxidants. Plant and animal reducing compounds such as vitamin $\mathrm{C}$, vitamin $\mathrm{E}$, carotenoids (xanthophylls and carotenes), anthocyanins, chalcones, isoflavones, tannins, flavandiols, and flavonols can restore the oxidative balance [Kasote et al., 2015]. Several epidemiological studies have demonstrated that individuals who consumed fruits, vegetables, and whole grains with anthocyanins, were at a lower risk to develop chronic diseases such as cancer, diabetes, and cardiovascular disease (CVD) [Pandey \& Rizvi, 2009]. Most of these beneficial health effects are attributed to exogenous antioxidant compounds ingested from plant sources at different concentrations. Anthocyanins are among the bioactive compounds that stand out for their beneficial properties [He \& Giusti, 2010].

Maize is widely distributed and consumed around the world, especially in developing countries. Because of this, some researchers have focused their efforts on the generation of new varieties of pigmented maize through cross-hybridization to obtain new varieties of grains with a greater 
antioxidant capacity [Tiessen et al., 2017]. Therefore, such improved maize varieties could function as bioactive agents and potential candidates to be included in the prevention and integral management of chronic degenerative diseases, and in reducing their incidence [Chander et al., 2008]. This review aimed to collect data on the effect of anthocyanins present in pigmented maize. They were considered regarding their metabolism, as well as their intervention in the antioxidant and modulating capacity of several cellular processes involved in oxidative stress such as cell growth, cell proliferation and cell death.

\section{OCCURRENCE OF ANTHOCYANINS AND THEIR CHEMICAL STRUCTURES}

Anthocyanins are responsible for many colors (blue, blue-black, red, and purple) of leaves, flowers, fruits, seeds, roots, and stems. In cereal grain (a kind of single-seed fruit), the anthocyanins are localized mainly in the cells of pericarp, testa, and aleurone layer, which depends on many structural and regulatory genes [Fan et al., 2016; Li et al., 2018]. Several plant foods contain different concentrations of anthocyanins including: berries (Morus and Rubus gender), grapes (Vitis), plums and cherries (Prunus), red pear (Pyrus), red apple (Malus), pomegranate (Punica), blackcurrants (Ribes), raspberry (Rubus), strawberries (Fragaria), chili (Capsicum) [Aza-Gonzalez \& Ochoa-Alejo, 2012], camu-camu (Myrciaria dubia) [Langley et al., 2015], açaí (Euterpe oleracea) [Peixoto et al., 2016], cacao (Theobroma) [Chavez-Rivera \& Ordoñez-Gomez, 2013], and calyces of Hibiscus sabdariffa L. (Jamaica) [Gurrola-Diaz et al., 2010], as well as such red radishes, red peppers, tomatoes, red onions, purple and red-fleshed potatoes (Solanum Tuberosum L.) [Jansen \& Flamme, 2006], purple cabbage (Brassica oleracea var. capitate), and eggplant (Solanum melongena L.) [Sadilova et al., 2006]. Anthocyanins are also present in grains such as in the color-varieties of corn (Zea), wheat (Triticum), rice (Oryza) [Goufo \& Trin- dale, 2014], and bean (Phaseolus) [Takeoka et al., 1997]. These foods (seeds, fruits, and vegetables) are the main source of natural pigments, which providing them unique colors and flavors and make them attractive for consumption, and eventually may serve in a complementary natural treatment of chronic diseases. In maize, they accumulate in structures such as stem, pod, leaves and inflorescences; in the cob, they are found in bracts, rachis, and kernels [Cui et al., 2012]. Chemically, the anthocyanins are polyhydroxy/polymethoxy glycosides derived from the anthocyanidins. They are formed by an anthocyanidin molecule, that is the aglycone, to which a sugar moiety is bound by a $\beta$-glycosidic bond or, in some cases, by $\alpha$-glycosidic bond. There are approximately 20 types of anthocyanidins in nature, but only six: pelargonidin (Pl), cyanidin (Cy), peonidin (Peo), delphinidin (Dp), petunidin $(\mathrm{Pt})$ and malvidin $(\mathrm{Mv})$, are widely distributed [Tsuda, 2012]. The name of these compounds is derived from the plant source from which they were first isolated. The basic chemical structure of aglycones is the flavylium ion, also called 2-phenyl-1-benzopyrylium (2-phenylchromenyl; IUPAC). It consists of a 15-carbon skeleton (C6-C3-C6) organized into two aromatic groups: benzopyrylium/chromenium, and phenolic (also known as hydroxycinnamoyl) (see Figure 1). Because of the trivalent character of oxygen, flavylium typically functions as a cation (oxonium ion) or flavylium salt [De Rosso et al., 2008].

The monosaccharides commonly bound by $\mathrm{O}$-glycosylation to the anthocyanidins, are glucose and rhamnose followed by galactose, xylose, arabinose, and occasionally, gentiobiose and raffinose [Horbowicz et al., 2008; Yonekura-Sakakibara et al., 2012; Fang, 2014]. All of them bind to anthocyanidin primarily by the hydroxyl group at the 3-position and secondarily at the 5 or 7-position but can also be found at positions 3', 5', or 6', but rarely at the 4' position. When two sugars are present in the same molecule, they are located in the 3 and 5 hydroxyl groups, producing a more stable structure than when a molecule contains only a single monosac-<smiles>[R9]C[C@H]1O[C@H](Oc2cc3c(O)cc(O)cc3[o+]c2-c2ccc(O)c([R7])c2)[C@H](O)[C@@H](O[R20])[C@H]1O</smiles><smiles>[R]C(=O)CC(=O)O</smiles>

Malonyl<smiles>[R]C(=O)CCC(=O)O</smiles>

Succinyl

\begin{tabular}{cc}
\hline $\mathrm{R}_{1}$ & Anthocyanidin \\
\hline$-\mathrm{H}$ & Pelargonidin \\
$-\mathrm{OH}$ & Cyanidin \\
$-\mathrm{OMe}$ & Peonidin \\
\hline
\end{tabular}

\begin{tabular}{|c|c|c|}
\hline $\mathrm{R}_{2}$ & $\mathrm{R}_{3}$ & Name \\
\hline $\mathrm{H}$ & $\mathrm{H}$ & Anthocyanidin-3-O- $\beta$-glucopyranoside \\
\hline $\mathrm{H}$ & Malonyl & Anthocyanidin-3-O-(6"'-malonyl-glucoside) \\
\hline Malonyl & Malonyl & Anthocyanidin-3-O-(3", 6"-dimalonyl-glucoside) \\
\hline $\mathrm{H}$ & Malonyl & Anthocyanidin-3-O-(6"-succinyl-glucoside) \\
\hline Succinyl & Succinyl & Anthocyanidin-3-O-(3", 6"-disuccinyl-glucoside) \\
\hline Malonyl & Succinyl & Anthocyanidin-3-O-(malonyl, succinylglucoside) \\
\hline
\end{tabular}

FIGURE 1. The structure of anthocyanin compounds isolated from maize. The enzymatic system of maize permits to yield three different anthocyanidins: pelargonidin, cyanidin, and peonidin, as well as their acylated derivatives: malonylated and succinylated ones [Abdel-Aal et al., 2006; Fossen et al., 2001]. 
charide. The combination of the anthocyanidins with the different sugars generates more than 700 different anthocyanins [Wallace \& Giusti, 2015]. The degree of glycosylation has a significant impact on the biological activity of the anthocyanin, depending on the chemical nature (type of carbohydrate) as well as the number and position of the glycosylation sites [Zhao et al., 2014]. Cereals like maize produce anthocyanins monoglycosylated with glucose, and later do acylation with one or two malonyl-CoA or succinyl-CoA [Fossen et al., 2001; Abdel-Aal et al., 2006] (see Figure 1).

Cyanidin is the major constituent of the pigmented maize grain and exhibits a significant antioxidant activity in comparison with that of the non-pigmented maize. In fact, its phytochemical composition and concentration of bioactive compounds vary depending on grain color, with a wide variety of tones ranging from black, blue, purple, red, yellow to white. Because it is a staple food providing a high anthocyanin content, there has been scientific interest in the study of pigmented maize and its health benefits [Lopez-Martinez et al., 2009]. Particularly, a similar profile of anthocyanin has been identified with different extraction methods (microwave, ultrasound, and maceration) like in the case of: cyanidin-3-(6"malonyl)-glucoside, cyanidin-3-O-glucoside and mainly peonidin-3-O-glucoside, pelargonidin-3-O-glucoside, pelargonidin-3-(6"malonyl)-glucoside, and peonidin-3-(6"malonyl)-glucoside [Salinas-Moreno et al., 2005a; Yang \& Zhai, 2010; Camelo-Méndez et al., 2016; Li et al., 2017; Chen et al., 2018; Fernandez-Aulis et al., 2019], however some differences in the anthocyanin profile are due to the environmental factors, maturity stages, and parts of the plant (husk, cob, and leaf) [Fossen et al., 2001; Li et al., 2008].

\section{STABILITY OF ANTHOCYANINS}

Anthocyanins are unstable and susceptible to degradation upon the effects of temperature, light, enzymes, $\mathrm{pH}$, and oxygen radicals. All these factors can affect their stability as well as their coloration intensity [Cevallos-Casals et al., 2004]. In aqueous solutions, anthocyanins suffer structure intramolecular adjustment mainly caused by the electronic deficiency (positive charge) of the flavylium nuclei. In vacuolar $\mathrm{pH}(4-6)$, the principal red flavylium (stable at $<3$ ) undergoes a proton loss, a water molecule addition, and an intramolecular rearrangement, generating the quinoid form with blue/violet coloration (at $\mathrm{pH}=4$ ), the colorless carbinol (at $\mathrm{pH}=5$ ), and chalcones with yellow coloration (at $\mathrm{pH}=6$ ), respectively [Kallam et al., 2017]. If pH keeps rising, the anionic forms start to accumulate, shifting the color of medium to green, when the ionized chalcone and ionized quinoid are in the equilibrium state at $\mathrm{pH} 8-10$ [Levi et al., 2004]. At pH values greater than 12 , dianion chalcone is the major compound, producing a yellow color in the solution [Petrov et al., 2013] (see Figure 2).

Two processes which can affect the stability and color of anthocyanins from maize are: the co-pigmentation, and the acylation [Cooper-Driver, 2001]. The co-pigmentation effect is a non-covalent intermolecular interaction with other phenolic compounds through a type $\pi$-stacking interaction (a property of aromatic rings), which enables the hy-

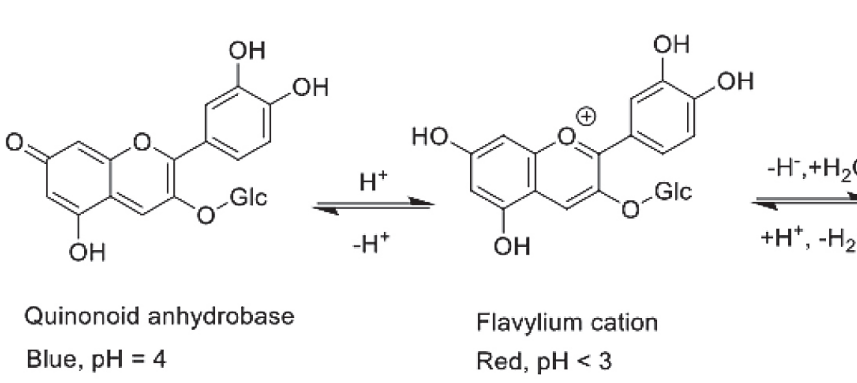<smiles>[C]O[C@@H](Cc1c(O)cc(O)cc1OCC)C(=O)c1ccc(O)cc1</smiles>

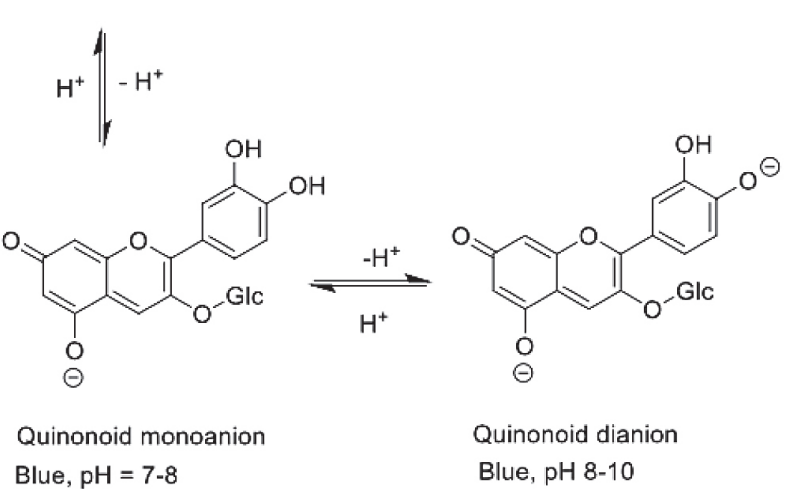
Colorless, $\mathrm{pH}=5$ Yellow, $\mathrm{pH}=6$<smiles>O=C(C[C@H](OCl)c1c(O)cc(O)cc1O)c1ccc(O)c(O)c1</smiles>

$\mathrm{Z}$ or $\mathrm{E}-\mathrm{Ch}$ alcone dianion Yellow, $\mathrm{pH}>12$

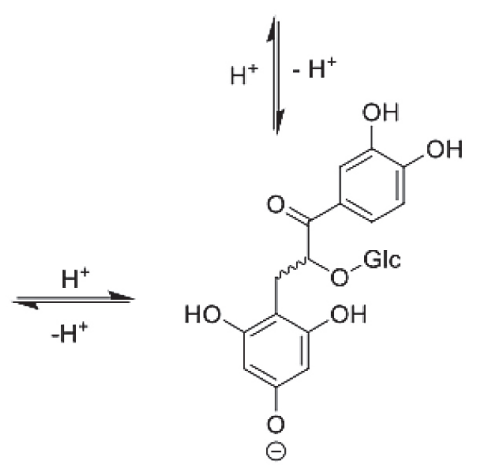

$\mathrm{Z}$ or E-Chalcone monoanion Yellow, $\mathrm{pH}=8-10$

FIGURE 2. Anthocyanin structural changes in aqueous medium at different pH. Cyanidin-3-O-glucoside is the structure shown; contains the most abundant aglycone in purple maize. In low $\mathrm{pH}(<3)$, the flavylium cation is the major chemical species, quinoid form with blue/violet coloration $(\mathrm{pH}=4)$, colorless carbinol $(\mathrm{pH}=5)$, and chalcones with yellow coloration $(\mathrm{pH}=6)$. The ionized chalcone and quinoid forms are in the equilibrium state at $\mathrm{pH} 8-10$. At $\mathrm{pH}$ values greater than 12, the yellow dianion chalcone is the major compound. 
perchromic shift in mildly acidic conditions through stabilizing blue quinoid species instead of carbinol compound in an aqueous medium [Mazza \& Brouillard, 1990]. The acylation with hydroxyl cinnamic acids (HCAs) can increase the number of interactions due to an extra phenyl ring [Gläßgen \& Seitz, 1992]. In the case of maize, the acylation occurs with malonyl and succinyl moieties, which cannot stabilize further the co-pigmentation, as happens for the acylation with HCAs [Harakotr et al., 2014]. Most of the aliphatic acylations are lost under an alkaline $\mathrm{pH}$, such as the nixtamalization process [Mora-Rochín et al., 2016].

ANTHOCYANINS IN PIGMENTED MAIZE
(ZEA MAYS L.)

The prehispanic cultures named the maize cob "centli" and the kernel "tlaolli" in their Nahuatl language. The earlier evidence for maize (Zea mays L.) domestication was estimated 8,700 calendrical years ago, found in Xihuatoxtla Shelter in Guerrero, Mexico [Piperno et al., 2009]. This grain constitutes one of the main sources of calories, proteins, and vitamins for the rural inhabitants of many regions including Mexico, central and north America. People in these regions have incorporated pigmented maize into their regular diets [Betrán et al., 2000]. There are many varieties of maize with different nutritional values, of which four varieties stand out: blue, red, yellow, and white [de la Parra et al., 2007]. Maize is commonly consumed in the form of dry mass flour to make "tortillas", chips, tamales, "gorditas", and many other basic foodstuffs of the Mexican and Latin American (e.g. different types of beverages).

Pigmented maize is a major source of starch, proteins, fats, sugars, anthocyanins, salicylic acid, resins, saponins, potassium, sodium salts, sulfur, phosphorus, and other phenolic compounds [Pedreschi \& Cisneros-Zevallos, 2007]. High concentrations of anthocyanins and phenolic compounds are distributed in the aleurone and pericarp monolayer of the grain, which provides the characteristic blue, red, purple, and black color to the maize varieties [Espinosa Trujillo et al., 2009]. Red and blue/purple beads are the most common [Salinas et al., 1999] and due to genetic variations, at least 59 races have been described in Mexico, many of them corresponding to variants of pigmented grains [Sanchez et al., 2000; Salinas-Moreno et al., 2013]. Žilić et al. [2012] reported differences in the anthocyanins content in several varieties of pigmented maize ranging from 2.50 to $696.07 \mathrm{mg} \mathrm{CGE} / \mathrm{kg}$ d.m. (cyanidin-3-O-glucoside equivalent per kilogram of dry mass). In this work, cyanidin-3-O-glucoside was the most abundant anthocyanin contained in the light blue maize variety. In another study conducted on blue maize planted in some regions of Mexico (Querétaro and Chihuahua States), Urias-Lugo et al. [2015a] confirmed the highest concentration at $1052 \mathrm{mg}$ $\mathrm{Cy} 3 \mathrm{glu} / \mathrm{kg}$ (cyanidin-3-O-glucoside for each $\mathrm{kg}$ of sample) of anthocyanins in the grain.

Anthocyanins in pigmented grains hold the promise of being functional food compounds due to their antioxidant and anti-inflammatory activity, phase II enzyme activators, anti-cell proliferation, and hypoglycemic effect [Tsuda et al., 2003; Urias-Peraldi et al., 2013]. Generally, the seeds have a high proportion of pigments in the aleurone layer and, to a lesser extent, in the starchy endosperm [Betrán et al., 2000]. The diversity of the varieties of pigmented maize is due to the physical characteristics such as the variability in the size, density, hardness, and chemical composition of the grain as well as environmental factors such as the climatic conditions where it grows, soil type, cultivation practices and finally, to specific genetic factors of each variety. The interaction of these factors provides to each variety of pigmented maize a unique observable characteristic such as coloration; but also, a different biological activity based on the quantity and profile of secondary metabolites, which enhances its functional food potential. For example, in light red-colored grains, the most abundant anthocyanidin is the pelargonidin [Salinas et al., 1999; Abdel-Aal et al., 2006], while in the blue grains (blue, purple, and black) the cyanidin derivatives prevail [Pedreschi \& Cisneros-Zeballos, 2007; Zhao et al., 2009]. In magenta red kernels, cyanidin derivatives predominate but they also contain derivatives of pelargonidin and peonidin [Salinas-Moreno et al., 2005a]. Specifically, the main anthocyanins reported in maize are cyanidin 3-O-glucoside and pelargonidin 3-O-glucoside that have been described in a relatively high proportion (about 40\%) as malonylated i.e., cyanidin 3-O-(6"-malonyl-glucoside) and cyanidin 3-O-(3",6"-dimalonyl-glucoside). The cobs of some landraces may contain kernels with up to three colors [Barrientos-Ramírez et al., 2018]. In the bluegrain varieties, the pigment is found in the aleurone layer, in those having light red grain - in the pericarp, and in those with magenta/red grain - it is located in both, the pericarp and aleurone layer [Salinas-Moreno et al., 2012]. There are both acylated and non-acylated anthocyanins in pigmented maize grains. Compared to other cereals, pigmented maize from Mexico exhibits a high concentration of anthocyanins of acylated type, which increases its chemical stability at extreme conditions of $\mathrm{pH}$ and temperature [de Pascual-Teresa et al., 2002; Salinas-Moreno et al., 2005a]. The acylated anthocyanins identified in the maize grain were cyanidin-3-O-glucoside, pelargonidin-3-O-glucoside, and peonidin 3-O-glucoside [Styles \& Ceska, 1972]. The sugar moiety might bind to one or more acyls (aliphatic acids such as malic, malonic, or succinic acid). In some cases, the acyl radicals can also come from cinnamic acids ( $p$-coumaric, caffeic, ferulic or synaptic) acting on glucose and rhamnose [Wang et al., 1997].

Several studies support the role of anthocyanins in suppressing free radicals and thereby in helping prevent and/or treat certain diseases such as atherosclerosis, diabetes, hypertension, inflammation, cancer, and also aging [Liu et al., 2012]. In addition, there is evidence that hybrid maize may contain high levels of nutraceutical compounds and could be considered an advantage for commercial production of tortillas and related food products with added value [Urias-Peraldi et al., 2013]. Currently in the food industry, maize anthocyanins have been used as dyes of many food products [Salinas-Moreno et al., 2005b]. However, the stability and function of maize anthocyanins depends on the type of cooking method, pretreatment, and combinations with other ingredients [Bello-Pérez et al., 2016].

"Nixtamalization" is the main process of transformation of maize for consumption that was developed by the Mexicas 
before the Precolumbian era. The word derives from the Nahuatl - nextli, ashes, and tamalli - cooked maize dough. This technology is still widely used in the American continent to obtain a wide variety of food products. The "nixtamalization" process involves chemical, structural, and nutritional changes in the various constituents of the grain [Rojas-Molina et al., 2007]. Because the nixtamalization process is a thermal-alkaline treatment that produces a decrease in anthocyanin content in pigmented maize, techniques such as fractional nixtamalization have been developed, which allows recovering approximately $58 \%$ of anthocyanins of pigmented maize probably because the endosperm and embryo layers are removed and nixtamalized separately. However, the nixtamalization by extrusion allows obtaining a greater quantity of anthocyanins in the blue maize (cyanidin 3-O-glucoside, equivalent to $620.9 \mathrm{mg} / \mathrm{kg}$ ) than in those of red, yellow, and white colors. Additionally, different anthocyanin derivatives are formed or even increased during the process, which modifies the anthocyanin profile [Escalante-Aburto et al., 2013a,b]. Besides, the nixtamalization processing of Mexican blue maize landraces has been found to increase the relative percentage of non-acylated anthocyanins (cyanidin-3-O-glucoside and peonidin-3-O-glucoside) and to decrease the relative percentage of acylated anthocyanins, such as cyanidin 3-O-(succinyl-glucoside) and cyanidine-3-O-(disuccinyl-glucoside), when compared to the raw kernels [Mora-Rochin et al., 2016]. All this can be useful in the selection of varieties of pigmented maize and their use as food products with a nutraceutical potential; which makes it necessary to search for methods that would improve grain processing and enable retaining a higher concentration of phenolic compounds, and subsequently evaluating the potential benefits to health through daily consumption under a controlled trial.

\section{BIOSYNTHESIS OF ANTHOCYANINS IN PIGMENTED MAIZE}

The characteristic coloration of each variety of pigmented maize grain is contained into genes related to the biosynthetic pathway of anthocyanins. This also includes maize varieties with white and yellow grains. The regulation of this pathway is directed by three families of transcriptional factors: $r$ (redl)/ bl(boosterl) family that belongs to the class of transcription factors type bHLH (basic helix-loop-helix), cl(colorless 1)/ pll (purple plant1)/pl(pericarp colorl) family corresponding to the MYB-like transcription factors, and WD40 factor PAC1 (pale aleurone color 1) [Sharma et al., 2011; Hu et al., 2016]. The expression of each member of this family occurs in a tissue-specific manner or during plant development. The pigmentation patterns of maize depend to a large extent on the allelic combination of the MYB and bHLH loci [Shen \& Petonilo, 2006]. For example, the dark blue color, typical of some grains of maize that develop in tropical climates, is generated by the allelic combination of the regulatory pll/ $B 1$ genes [Lago et al., 2013, 2014]. This allelic combination can activate mainly the synthesis of cyanidin-3-O-glucoside in the pericarp and some tissues of the maize plant. Whereas $\mathrm{rl} / \mathrm{cl}$ combination is required for the accumulation of pel-
argonidin-3-O-glucoside in the aleurone layer [Cone, 2007; Sharma et al., 2011; Li et al., 2019].

\section{BIOAVAILABILITY OF ANTHOCYANINS}

In animal and human studies, it has been reported that anthocyanins are rapidly absorbed as glycosides in the stomach and small intestine, mainly in the jejunum section so that they can reach many peripheric tissues and modulate metabolic changes in the organism [Talavéra et al., 2004; Kay et al., 2005]. On the other hand, despite the intake of anthocyaninrich foods, the plasma concentration of these compounds remains very low [Manach et al., 2005]. It is suggested that they have a low rate of bioavailability [Bitsch et al., 2004; Felgines et al., 2005; Tian et al., 2006]. Some causes of low bioavailability are due to their chemical structure, excretion with feces, instability at neutral $\mathrm{pH}$ [Mullen et al., 2006; Bub et al., 2001], metabolism of the intestinal microbiota [Aura et al., 2005], effect of the intestinal mucosa, and hepatic metabolism. Despite the low bioavailability, some beneficial effects may be caused by the metabolites such as protocatechuic acid (a major metabolite of anthocyanins in humans with antimicrobial and antioxidant effects) [Wang et al., 2010].

The relative composition of the different molecular structures of the anthocyanins coexisting in an aqueous solution at any given time depends on the $\mathrm{pH}$, temperature, concentration, and time. This is particularly important since anthocyanins are exposed to different $\mathrm{pH}$ conditions throughout the gastrointestinal tract, which affects their bioavailability and therefore their bioactivity and/or pharmacodynamics [McGhie \& Walton, 2007]. Intake of foods rich in anthocyanins for a prolonged time favored the accumulation of these compounds in several tissues but not in the plasma and urine [Kalt et al., 2008].

In addition, the type of food matrix significantly affected the absorption of anthocyanins [Yang et al., 2011]. In vitro and in vivo studies have shown that the properties of aglycone, sugar, and the presence of acyl radicals can influence the absorption and metabolism of anthocyanins, being biotransformed mainly by conjugation with glucoronic acid and also by methylation reactions [de Ferrars et al., 2014].

On other hand, the microbiota plays a special role in the metabolism of anthocyanins, which reach the colon in two ways. In the first one, they cannot be absorbed by the stomach and small intestine whereas in the second, the anthocyanins are excreted in the bile after absorption in the stomach and duodenum. Subsequently, after reaching the colon, the anthocyanins are hydrolyzed to liberate the glycosylated fraction of the aglycone and consequently degrade into phenolic acids, which are more susceptible to reabsorption [Kay, 2006].

In regard to their elimination, the number of anthocyanins excreted by urine is low and the mechanism of excretion depends on how and where anthocyanins are biotransformed. Studies with oral administration of purple maize in broilers showed that the anthocyanins did not affect the biochemical parameters and histopathology characteristics although they were presented in the skin, urine, and feces [Nabae et al., 2008; Amnueysit et al., 2010]. In most reports, 
the mechanism describing the elimination of anthocyanins through feces is limited because anthocyanins are converted in other compounds by microbiota action [Couteau et al., 2001]. For example, glucose-bound aglycones are less stable to the action of the $\beta$-glucosidase enzyme of the small intestine compared to galactose-binding aglycones. This instability upon intestinal enzymes action can probably be attributed to the action of the microbiota. It should be also noted that acylated anthocyanins with $p$-coumaric acid or a second sugar in their structure are resistant to degradation and render them susceptible to reabsorption in the small intestine [He et al., 2005]. Although the bioavailability studies of anthocyanins from other plants could be applied to pigmented maize, not enough in vitro and in vivo studies have been reported to provide pharmacokinetic data about their bioavailability.

\section{EFFECT OF THE NUTRACEUTICAL POTENTIAL OF ANTHOCYANINS FROM PIGMENTED MAIZE ON OXIDATIVE STRESS}

The antioxidant capacity of the extracts of pigmented maize is mainly due to the phenolic compounds that they contain. Of these, the aglycones have a superior activity to that of anthocyanins because of a greater number of sugars in the molecule [Serna-Saldivar et al., 2013]. The in vitro and in vivo studies of anthocyanins have shown a wide spectrum of their antioxidant effects. Among those, stands out the reduction of free radical absorption capacity, the stimulation of phase II enzymes for the detoxification, as well as the reduction of oxidative products formation in the DNA and lipids peroxidation. For example, sheep fed with diets based on anthocyanin-rich maize silage showed no significant change in the plasma total antioxidant status (TAS) in comparison to these administered the control diet [Hosoda et al., 2012]. However, it has been reported that the intake of anthocyanins in vivo increases plasma/serum antioxidant capacity (PAC) in golden Syrian hamsters and human subjects, respectively [Mazza et al., 2002; Auger et al., 2004].

Besides, anthocyanins have been found to offer the protection against mutagenesis caused by environmental and carcinogenic toxins and the modulation of specific signaling pathways for cell proliferation [Wang \& Stoner, 2008]. Some of these effects are summarized in Table 1, highlighting results from extraction protocols (aqueous or hydroalcoholic). The general biological responses involve the upregulation of enzymes and the activation of mechanisms that protect cells and organisms from oxidant agents (radicals) and from oxidative stress damage (due to the redox imbalance), which is a common feature in the development of non-communicable diseases.

\section{ANTIOXIDANT CAPACITY OF ANTHOCYANINS}

The scientific interest in food anthocyanins has increased because they have been shown capable of preventing cellular oxidative stress [Prior, 2003]. The antioxidant activity of anthocyanins depends mainly on the aglycone molecule but may also be affected by covalently bound sugars altering solubility and membrane permeability. Anthocyanins have an adequate chemical structure to act as antioxidants, which allows them to donate hydrogens [Rice-Evans et al., 1997; Wang et al., 1999] or electrons to free radicals or to trap them and move them in their aromatic structure [Ramírez-Tortosa et al., 2001]. Optimal antioxidant activity is related to the presence of hydroxyl groups in the 3' and 4' positions of the B ring, which confer molecular stability to the formed radical [Kongpichitchoke et al., 2015]. While the free hydroxyl group in the 3 position of the $\mathrm{C}$ ring and the 5 position of the ring A, are electron donors [Rice-Evans et al., 1996]. In the same sense, the antioxidant capacity of anthocyanins is due to their flat structure, which allows a greater delocalization of electrons through the rings [Dangles \& Elhajji, 1994]. In the maize, it has been reported that maize cyanidin derivatives are more potent antioxidant agents than those of delphinidin. In addition, cyanidin has a greater antioxidant power if the glycosylated sugar is a rhamnose rather than glucose [Abdel-Aal et al., 2008].

Furthermore, glucosides identified in the rose variety of maize, like cyanidin, pelargonidin and peonidin, being cyanidin-3-(6-malonyl-glucoside) a malonic derivative cyanidin, are probably responsible for its grain color as well as its nutraceutical value [Barrientos-Ramírez et al., 2018]. Accordingly, in one study with waxy corn a significant $(r=0.70)$ correlation was reported between TAC (total anthocyanin content) and DPPH (2,2-diphenyl-1-picryl-hydrazyl-hydrate) assay and a moderate correlation between TPC (total phenolic content), DPPH, and TEAC (Trolox equivalent antioxidant capacity) ( $r=0.60$ and $r=0.76$, respectively). These results confirm that the antioxidant capacity of anthocyanins depends largely on the type and amount of cyanidin glucosides and not only on the quantity of total polyphenols of the maize kernel [Duangpapeng et al., 2019]. On the other hand, in blue maize, the anthocyanin profile showed primarily acylated cyanidins and pro-anthocyanidins in raw and nixtamalized extracts. Results from the DPPH assay showed that the antioxidant capacity in the blue maize tortilla extract had slightly lower values ( $45.1 \mu \mathrm{M} \mathrm{ET/g}$ fresh weight) than raw blue maize extract $(49.2 \mu \mathrm{M} \mathrm{ET/g}$ fresh weight). It can be explained because of the nixtamalization process in the tortilla's manufacturing which modifies the type and content of anthocyanins in the grain. Nevertheless, both extracts reduced the TBARS production in homogenized rat brains $\left(\mathrm{IC}_{50}=792 \mathrm{mg} / \mathrm{mL}\right.$ and $\mathrm{IC}_{50}=750 \mathrm{mg} / \mathrm{mL}$, respectively). These findings suggest that the nixtamalization process improves the biological anthocyanin's properties [Herrera-Sotero et al., 2017]. Finally, these results show also that the antioxidant activity of anthocyanins depends on the type, number, and glycosylation site in the molecule of anthocyanidins contained in the maize kernel as well as methodology used to evaluate the antioxidant capacity of these compounds [Zhao et al., 2014].

\section{OTHER BIOLOGICAL EFFECTS}

Long-term ingestion of pigmented maize anthocyanins protected rat hearts against ischemia-reperfusion injury [Toufektsian et al., 2008]. Besides, a study with mice reported that the anthocyanins from black rice, black soybean, 
and purple maize increased the fecal butyric acid content, as well as ameliorated diet-induced obesity by reducing both oxidative stress and inflammation [Wu et al., 2017]. Other properties of anthocyanins have been described as antimicrobial and antiproliferative activities [Cisowska et al., 2011]. These abilities been evaluated in extracts of anthocyanins from some types of native pigmented maize varieties in which the authors identified five anthocyanin compounds: cyanidin 3-O-glucoside, peonidin 3-O-glucoside, pelargonidin 3-O-glucoside, cyanidin 3-O-(6"-malonyl-glucoside), and cyanidin 3-O-(3", 6"-dimalonyl-glucoside), [Salinas-Moreno et al., 2005a]. IC I0 $_{\text {of }}$ Chinese purple maize extract was reported against pathological strains of S. enteritidis $(5 \mathrm{mg} / \mathrm{mL}), S$. aureus $(10 \mathrm{mg} / \mathrm{mL})$ and $C$. albicans $(25 \mathrm{mg} / \mathrm{mL})$ in a dose-dependent manner [Zhao et al., 2009]. Moreover, another study determined the antimicrobial ability of anthocyanins isolated from the cob of purple maize. A significant antifungal activity of anthocyanins was observed in fluconazole-resistant strains of $C$. glabrata, C. krusei, and C. parapsilosis with MIC (Minimum Inhibitory Concentration) ranging from 0.625 to $2.5 \mathrm{mg} /$ $\mathrm{mL}$ [Suket et al., 2014]. Furthermore, the antimicrobial activities of free and bound phenolic fractions from Peruvian purple maize were compatible with the survival of $L$. helveticus and B. longum (probiotic bacteria). Nonetheless, none of these fractions could inhibit the growth of pathogenic H. pylori [Galvez-Ranilla et al., 2017]. On the other hand, it has been reported that maize phenolic compounds could decrease starch digestibility by a specific anthocyanin-starch interaction [Hernández-Uribe et al., 2007; Camelo-Méndez et al., 2016], and also inhibit digestive enzymes involved in the absorption of carbohydrates. Moreover, it has been suggested that the use of pigmented maize flours might help in the formulation of gluten-free products with slowly digestible starches [Rocchetti et al., 2018].

Extracts of maize anthocyanins counteracted the proliferation of cancer cell lines. The antiproliferative capacity of anthocyanins was dose-dependent $\left(\mathrm{IC}_{50}=0.525 \mu \mathrm{g} / \mathrm{mL}\right)$ in HT29 cells [Zhao et al., 2009]. Also, some authors [Urias-Lugo et al., 2015b] demonstrated that breast carcinoma (MCF7), hepatic (HepG2), colon carcinoma (Caco2 and HT29), and prostate carcinoma (PC3) cell lines treated with acidified extracts of anthocyanins of hybrid blue maize presented greater antiproliferative effect. The isomer cyanidin malonylglucoside I reduced the cell viability in Caco2, HepG2, MCF7, and PC3 cells, suggesting that acylated compounds inhibit the growth of cancer cells. Cyanidin 3-O-glucoside from purple maize suppressed Ras protein levels and inhibited 7,12-dimethylbenzo-anthracene [Guillen-Sanchez et al., 2014], which induce mammary carcinogenesis in rats, suggesting that it may act as a potential chemotherapeutic agent [Fukamachi et al., 2008]. In addition, Navolokin et al. [2012] studied the effect of anthocyanin extracts from maize and observed reduced endogenous intoxication in rats with transplanted tumor suspension of liver cancer PC-1 cells.

Anthocyanins derived from the variety Zea mays var. Kculli (purple maize) improved insulin secretion of pancreatic beta cells in $\mathrm{db} / \mathrm{db}$ mice compared to glimepiride (a sulfonylurea) but also protected pancreatic beta cells from apoptosis in cul- tures of the HIT-T15 cell line after treatment with the sulfonylurea, which increases the concentration of $\mathrm{H}_{2} \mathrm{O}_{2}$ [Hong et al., 2013]. Interestingly, the mechanism of action of the anthocyanin extract of purple maize on insulin secretion differed from that of the GLP/GLP receptor/cAMP/PKA signal for insulin secretion. Extracts of purple maize $(50 \mathrm{mg} / \mathrm{kg}$ purple maize extract) induced phosphorylation of AMP-activating protein kinase (AMPK), decreased expression of phosphoenolpyruvate carboxy kinase (PEPCK) and glucose-6-phosphatase (G6pase) in liver, and also increased the expression of the glucose transporter 4 (GLUT4) of skeletal muscle in C57BL/KsJ $\mathrm{db} / \mathrm{db}$ mice. The authors suggested that the extracts exhibited antidiabetic activity through the protection of the pancreatic cells against ROS, increased the production and secretion of insulin, and activated the AMPK in the liver [Huang et al., 2015]. In addition, other results indicate that the anthocyanin extract from the purple maize can be used in combination with the conventional treatment of type 2 diabetes and thus may improve the function of the pancreatic beta cells [Kang et al., 2013]. Another study reported that purple maize anthocyanins, in particular cyanidin 3-O-glucoside and cyanidin-3-O-(6"-malonyl-glucoside), attenuated the proliferation of mesangial cells and protein accumulation of extracellular matrix "mesangium and glomerular basal membrane" (a diabetic glomerulosclerosis characteristic) in human mesangial cells stimulated by a high concentration of glucose through the inactivation of NF- $\mathrm{B}$ translocation. This effect enhanced the signaling of transforming growth factor beta (TGF- $\beta$ ), as well as promoted the degradation of the extracellular matrix [Li et al., 2012a]. Similarly, Roh et al. [2016] investigated the anti-inflammatory effects of Zea mays L. husk extracts and found a downregulation of the inducible nitric oxide synthase (iNOS) gene expression mediated by $\mathrm{NF}-\kappa \mathrm{B}$ and AP-1 signaling in RAW256.7 cells.

In a model of in vitro inflammation of mono- or co-culture of macrophage or/and adipocyte cells treated with extracts rich in anthocyanins from purple and red maize, Zhang et al. [2019] showed an inhibition of NF- $\kappa$ B and JNK pathways via regulation of $\mathrm{I} \kappa \mathrm{B} \alpha$ and $\mathrm{JNK}$ phosphorylation. Besides, these extracts decreased pro-inflammatory cytokine production and lipolysis, and enhanced the glucose transporter 4 membrane (GLUT4) translocation [Zhang et al., 2019]. Additionally, the anthocyanin-rich purple maize extract increased free fatty acid receptor-1 (FFAR1) and glucokinase (GK) activity in Caco-2, INS-1E, and HepG2 cells culture [Luna-Vital \& de Mejía, 2018].

On the other hand, when an anthocyanin complex (prepared with dried petals of blue butterfly pea (C.ternatea L.), dried rhizomes of turmeric ( $C$. longa) and dried purple waxy corn cobs (Z. mays L. ceritina Kulesh) was given to hamsters infected with Opisthorchis viverrini (an experimental model of inflammation and periductal fibrosis in liver), Intuyod et al. [2014] found reduced number of inflammatory cells and periductal fibrosis in this model. Besides, in the treated animals there were reduced the formation of 8-oxodG (an oxidative DNA damage marker), NF- $\mathrm{B}$ expression, iNOS synthesis, and oxidative stress. Contrarily, the gene expression of CAT, SOD, and GPx was increased in the treated experimental group [Intuyod et al., 2014]. 


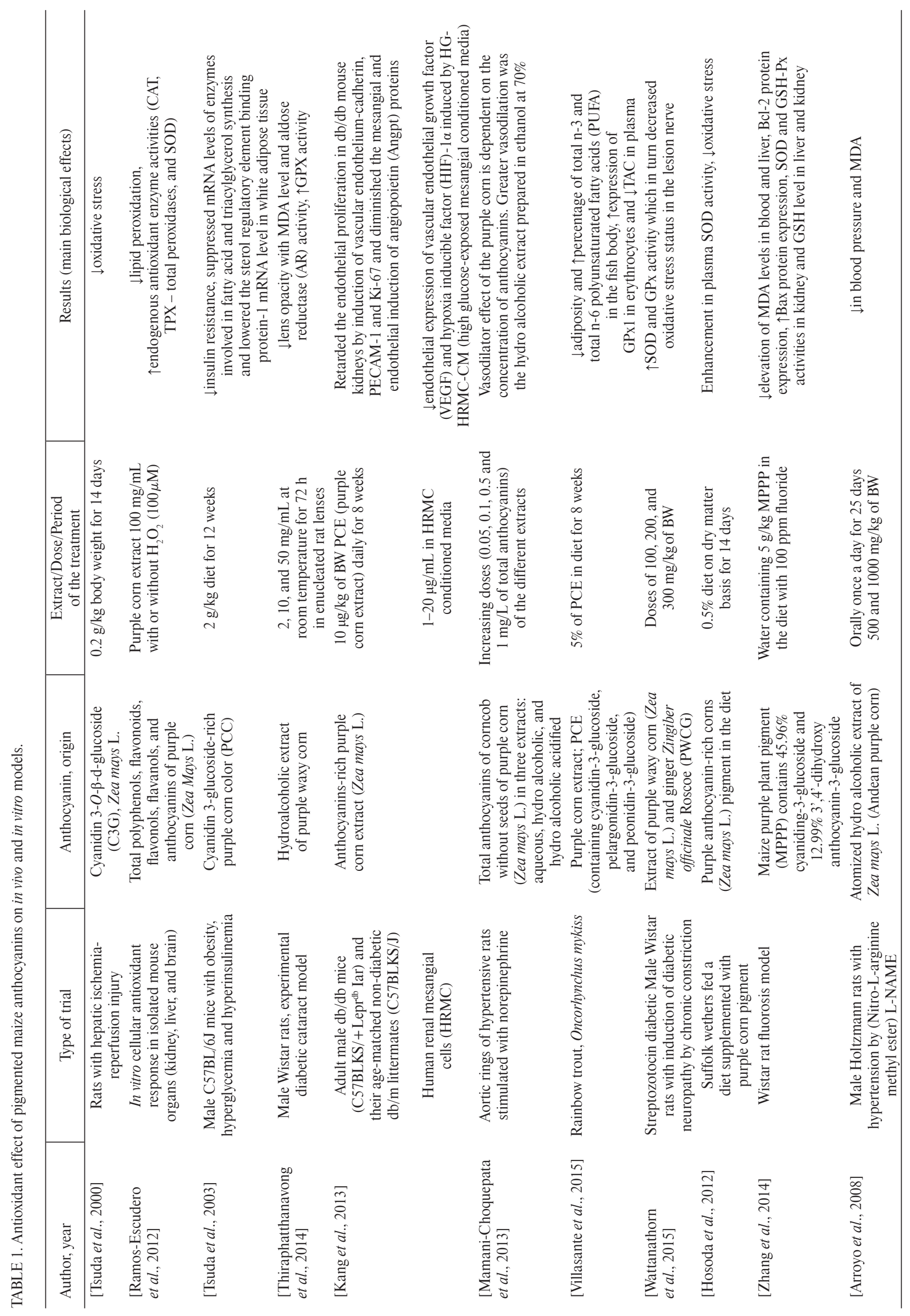




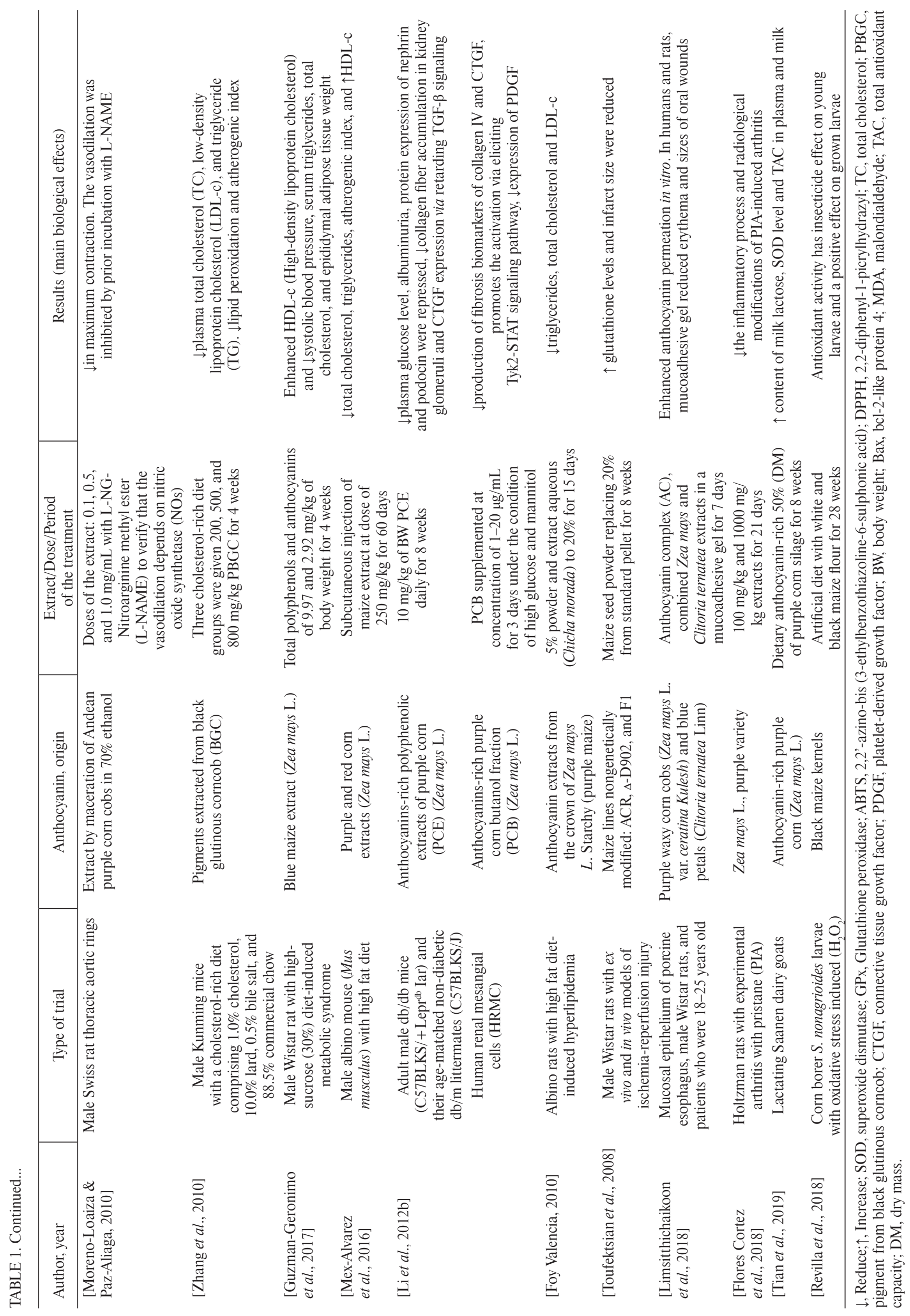




\section{CONCLUSION}

Anthocyanins represent a promising class of antioxidants found naturally in plants that enhance their stress resistance and nutritional value through diverse biological mechanisms. Several studies in vitro and in vivo corroborate the antioxidant and biological effect of maize anthocyanins. The aging of the population and the exponential increase of governmental health expenses make it necessary to implement natural and cost-effective alternatives for the prevention and management of diseases caused by redox disequilibrium and cell aging. Maize is a staple crop widely accepted as food ingredient; therefore, it could be useful as a functional additive to prevent aging, obesity, and metabolic syndrome. Its permanent consumption could also reduce the increase of cases with chronic degenerative diseases such as diabetes, cancer, and cardiovascular diseases. Antioxidant efficacy of pigmented maize anthocyanins has been less documented in both in vivo and in vitro studies possibly due to the scarce knowledge of their bioavailability and pharmacokinetics. Besides, there is a wide diversity of anthocyanins that can be found in plants. This represents a methodological problem for reductionistic experimental approaches, since it requires the previous analysis of extracts for the exact chemical identification and characterization of the anthocyanins/polyphenols of each sample batch. There are equipment/infrastructure limitations for the determination of molecular structures and the antioxidant in vitro activity as well. Uniformity in the elaboration of the extracts, methodologies of quantification, and report of new results is also needed. Another important circumstance to be considered is the food manufacture process that simultaneously alters a large number of molecules. The process and secondary ingredients that best enhance the nutraceutical potential of colored maize are yet unknown, but we might learn the empirical lessons of centuries of the Mesoamerican culinary culture mixing for example, roasted maize, chili, chia seeds, and cacao beans. In conclusion, pigmented maize has properties that need to be exploited and thoroughly investigated. We expect that this review highlights the importance of anthocyanins from pigmented maize as well as its biological effects in order to promote further research in this field and increase the knowledge of the beneficial properties it offers to the health through its consumption.

\section{RESEARCH FUNDING}

This work was supported by grants from the Consejo Nacional de Ciencia y Tecnología (CONACYT Mexico) to AT. We acknowledge support from the National Laboratory PlanTECC, Problemas Nacionales e Infraestructura. We further acknowledge initial funding grants by SAGARPA through CIMMYT and the MasAgro initiative. CONACYT. PN2015-613, LN2018-293362.

\section{ACKNOWLEDGEMENTS}

We thank Pedro M. García-López (CUCBA, University of Guadalajara), Andres Estrada Luna and Norma Cecilia Morales Elias for technical support. We also thank Francisco Orozco Montes, Adrian Garcia Casarrubias, Edgar Cubedo
Lopez, Sheila Juarez Colunga, Jesus Ruben Torres Garcia, Alberto Camas Reyes and Julio Armando Massange-Sanchez for their help.

\section{CONFLICT OF INTERESTS}

Authors declare no conflict of interest.

\section{REFERENCES}

1. Abdel-Aal, E.S., Abou-Arab, A., Gamel, T., Hucl, P., Young, J., Rabalski, I. (2008). Fractionation of blue wheat anthocyanin compounds and their contribution to antioxidant properties. Journal of Agricultural and Food Chemistry, 56(23), 11171-11177.

2. Abdel-Aal, E.S.M., Young, J.C., Rabalski, I. (2006). Anthocyanin composition in black, blue, pink, purple, and red cereal grains. Journal of Agricultural and Food Chemistry, 54(13), 4696-4704.

3. Amnueysit, P., Tatakul, T., Chalermsan, N., Amnueysit, K. (2010). Effects of purple field corn anthocyanins on broiler heart weight. Asian Journal of Food and Agro-Industry, 3(3), 319-327.

4. Arroyo, J., Raez, E., Rodríguez, M., Chumpitaz, V., Burga, J., De la Cruz, W., Valencia, J. (2008). Antihypertensive and antioxidant activity of atomized Andean purple corn (Zea mayz L.) hydroalcoholic extract in rats. Revista Peruana de Medicina Experimental y Salud Publica, 25(2), 195-199 (in Spanish; English abstract).

5. Auger, C., Laurent, N., Laurent, C., Besançon, P., Caporiccio, B., Teissédre, P.L., Rouanet, J.M. (2004). Hydroxycinnamic acids do not prevent aortic atherosclerosis in hypercholesterolemic golden Syrian hamsters. Life Sciences, 74(19), 2365-2377.

6. Aura, A.M., Martin-Lopez, P., O'Leary, K.A., Williamson, G., Oksman-Caldentey, K.M., Poutanen, K., Santos-Buelga, C. (2005). In vitro metabolism of anthocyanins by human gut microbiota. European Journal of Nutrition, 44(3), 133-142.

7. Aza-Gonzalez, C., Ochoa-Alejo, N. (2012). Characterization of anthocyanins from fruits of two Mexican chili peppers (Capsicum annuum L.). Journal of the Mexican Chemical Society, 56(2), 149-151.

8. Barrientos-Ramírez, L., Ramírez-Salcedo, H.E., Fernández-Aulis, M.F., Ruíz-López, M.A., Navarro-Ocaña, A., Vargas-Radillo, J.J. (2018). Anthocyanins from rose maize (Zea mays L.) grains. Interciencia, 43(3), 188-192.

9. Bello-Pérez, L.A., Camelo-Mendez, G.A., Agama-Acevedo, E., Utrilla-Coello, R.G. (2016). Nutraceutic aspects of pigmented maize: digestibility of carbohydrates and anthocyanins. Agrociencia, 50(8), 1041-1063.

10. Betrán, F.J., Bockholt, A.J., Rooney, L.W. (2000). Blue corn. In A.R. Hallauer (Ed.), Specialty Corns, Second Edition, CRC Press, Boca Raton, Florida, USA, pp. 305-314.

11. Birben, E., Sahiner, U.M., Sackesen, C., Erzurum, S., Kalayci, O. (2012). Oxidative stress and antioxidant defense. World Allergy Organization Journal, 5(1), 9-19.

12. Bitsch, R., Netzel, M., Frank, T., Strass, G., Bistch, I. (2004). Bioavailibility and biokinetics of anthocyanins from red grape juice and red wine. Journal of Biomedicine \& Biotechnology, 2004(5), 293-298.

13. Bub, A., Watzl, B., Heeb, D., Rechkemmer, G., Briviba, K. (2001). Malvidin-3-glucoside bioavailability in humans after ingestion of red wine, dealcoholized red wine and red grape juice. European Journal of Nutrition, 40(3), 113-120. 
14. Camelo-Méndez, G.A., Agama-Acevedo, E., Sanchez-Rivera, M.M., Bello-Pérez, L.A. (2016). Effect on in vitro starch digestibility of Mexican blue maize anthocyanins. Food Chemistry, 211, 281-284.

15. Cevallos-Casals, B.A., Cisneros-Zevallos, L. (2004). Stability of anthocyanin-based aqueous extracts of Andean purple corn and red-fleshed sweet potato compared to synthetic and natural colorants. Food Chemistry, 86(1), 69-77.

16. Chander, S., Meng, Y.J., Zhang, Y.R., Yan, J.B., Li, J.S. (2008). Comparison of nutritional traits variability in selected eightyseven inbreds from Chinese maize (Zea mays L.) germplasm. Journal of Agricultural and Food Chemistry, 56(15), 6506-6511.

17. Chavez-Rivera, R., Ordoñez-Gomez, E. (2013). Total polyphenols, anthocyanins and antioxidant capacity (DPPH and ABTS) during processing of cocoa liquor and cocoa powder. Revista ECIPerú, 10(1), 42-50 (in Spanish; English abstract).

18. Chen, L., Yang, M., Mou, H., Kong, Q. (2018). Ultrasoundassisted extraction and characterization of anthocyanins from purple corn bran. Journal of Food Processing and Preservation, 42(1), art. no. e13377.

19. Cisowska, A., Wojnicz, D., Hendrich, A.B. (2011). Anthocyanins as antimicrobial agents of natural plant origin. Natural Product Communications, 6(1), 149-156.

20. Cone, K.C. (2007). Anthocyanin synthesis in maize aleurone tissue. In O.-A. Olsen (Ed.) Endosperm. Developmental and Molecular Biology, Springer, Berlin, Heidelberg, Germany, pp. 121-139.

21. Cooper-Driver, G.A. (2001). Contributions of Jeffrey Harborne and co-workers to the study of anthocyanins. Phytochemistry, 56(3), 229-236.

22. Couteau, D., McCartney, A.L., Gibson, G.R., Williamson, G., Faulds, C.B. (2001). Isolation and characterization of human colonic bacteria able to hydrolyse chlorogenic acid. Journal of Applied Microbiology, 90(6), 873-881.

23. Cui, L., Gao, R., Dong, S., Zhang, J., Liu, P., Zhang, H., Meng, J., Shi, D. (2012). Effects of ear shading on the anthocyanin contents and quality of kernels in various genotypes of maize. Australian Journal of Crop Science, 6(4), 704-710.

24. Dangles, O., Elhajji, H. (1994). Synthesis of 3-methoxyand 3-( $\beta$-D-glucopyranosyloxy) flavylium ions. Influence of the flavylium substitution pattern on the reactivity of anthocyanins in aqueous solution. Helvetica Chimica Acta, 77(6), 1595-1610.

25. de Ferrars, R.M., Czank, C., Zhang, Q., Botting, N.P., Kroon, P.A., Cassidy, A., Kay, C.D. (2014). The pharmacokinetics of anthocyanins and their metabolites in humans. British Journal of Pharmacology, 171(13), 3268-3282.

26. de la Parra, C., Serna Saldivar, S.O., Hai, L.R. (2008). Effect of processing on the phytochemical profiles and antioxidant activity of corn production of masa, tortillas and tortilla chips. Journal of Agricultural and Food Chemistry, 55(10), 4177-4183.

27. de Pascual-Teresa, S., Santos-Buelga, C., Rivas-Gonzalo, J. (2002). LC-MS analysis of anthocyanins extracts from purple corn cob. Journal of the Science of Food and Agriculture, 82(9), 1003-1006.

28. De Rosso, V.V., Moran Vieyra, F.E., Mercadante, A.Z., Borsarelli, C.D. (2008). Singlet oxygen quenching by anthocyanin's flavylium cations. Free Radical Research, 42(10), 885-891.

29. Duangpapeng, P., Lertrat, K., Lomthaisong, K., Paul Scott, M., Suriharn, B. (2019). Variability in anthocyanins, phenolic com- pounds and antioxidant capacity in the tassels of collected waxy corn germplasm. Agronomy - Basel, 9(3), art. no. 158.

30. Escalante-Aburto, A., Ramirez-Wong, B., Torres-Chavez, P.I., Barron-Hoyos, J.M., Figueroa-Cardenas, J.D., Lopez-Cervantes, J. (2013a). The nixtamalization process and its effect on anthocyanin content of pigmented maize, a review. Revista Fitotecnia Mexicana, 36(4), 429-437 (in Spanish; English abstract).

31. Escalante-Aburto, A., Ramirez-Wong, B., Torres-Chavez, P.I., Figueroa-Cardenas, J.D., Lopez-Cervantes, J., Barron-Hoyos, J.M., Morales Rosas, I. (2013b). Effect of extrusion processing parameters on anthocyanin content, physicochemical properties of nixtamalized blue corn expanded extrudates. CyTA - Journal of Food, 11, SI, 29-37.

32. Espinosa Trujillo, E., Mendoza Castillo, M., Castillo Gonzalez, F., Ortiz Cereceres, J., Delgado Alvarado, A., Carrillo Salazar, A. (2009). Anthocyanin accumulation in pericarp and aleurone layer of maize kernel and their genetic effects on native pigmented varieties. Revista Fitotecnia Mexicana, 32(4), 303-309 (in Spanish; English abstract).

33. Fan, X., Fan, B., Wang, Y., Yang, W. (2016). Anthocyanin accumulation enhanced in Lc-transgenic cotton under light and increased resistance to bollworm. Plant Biotechnology Reports, 10(1), 1-11.

34. Fang, J. (2014). Bioavailability of anthocyanins. Drug Metabolism Reviews, 46(4), 508-520.

35. Felgines, C., Talavera, S., Texier, O., Gil-Izquierdo, A., Lamaison, J.L., Remesy, C. (2005). Blackberry anthocyanins are mainly recovered from urine as methylated and glucuronidated conjugates in humans. Journal of Agricultural and Food Chemistry, 53(20), 7721-7727.

36. Fernandez-Aulis, F., Hernandez-Vazquez, L., Aguilar-Osorio, G., Arrieta-Baez, D., Navarro-Ocana, A. (2019). Extraction and identification of anthocyanins in corn cob and corn husk from Cacahuacintle maize. Journal of Food Science, 84(5), 954-962.

37. Flores-Cortez, D., Villalobos-Pacheco, E., Rojo-Mejia, A., Palomino-Yamamoto, P., Martin-Ramírez, Y. (2018). Osteoarticular protection of Zea mays L. purple variety (purple corn) in experimental arthritis in rats. Revista Peruana de Medicina Experimental y Salud Pública, 35(3), 441-448 (in Spanish; English abstract).

38. Fossen, T., Slimestad, R., Andersen, Ø.M. (2001). Anthocyanins from maize (Zea mays) and reed canarygrass (Phalaris arundinacea). Journal of Agricultural and Food Chemistry, 49(5), 2318-2321.

39. Foy Valencia, E. (2010). Los efectos de las antocianinas extraídas de Zea mays L. (maíz morado) sobre las hiperlipidemias en ratas albinas. Biotempo, 10, 32-38 (in Spanish; English abstract).

40. Fukamachi, K., Imada, T., Ohshima, Y., Xu, J., Tsuda, H. (2008). Purple corn color suppresses Ras protein level and inhibits 7,12-dimethylbenz[a]antracene-induced mamary carcinogenesis in the rat. Cancer Science, 99(9), 1841-1846.

41. Galvez Ranilla, L., Christopher, A., Sarkar, D., Shetty, K., Chirinos, R., Campos, D. (2017). Phenolic composition and evaluation of the antimicrobial activity of free and bound phenolic fractions from a Peruvian purple corn (Zea mays L.) accession. Journal of Food Science, 82(12), 2968-2976.

42. Gläßgen, W.E., Seitz, H.U. (1992). Acylation of anthocyanins with hydroxycinnamic acids via 1-O-acylglucosides by protein preparations from cell cultures of Daucus carota L. Planta, 186(4), 582-585. 
43. Goufo, P., Trindale, H. (2014). Rice antioxidants: phenolic acids, flavonoids, anthocyanins, proanthocyanidins, tocopherols, tocotrienols, $\gamma$-oryzanol, and phytic acid. Food Science and Nutrition, 2(2), 75-104.

44. Guillen-Sanchez, J., Mori-Arismendi, S., Paucar-Menacho, L. (2014). Characteristics and functional properties of purple corn (Zea mays L.) var. subnigroviolaceo. Scientia Agropecuaria, 5, 211-217 (in Spanish; English abstract).

45. Gurrola-Diaz, C., Garcia-Lopez, P., Sanchez-Enriquez, S., Troyo-Sanroman, R., Andrade-Gonzalez, I., Gomez-Leyva, J. (2010). Effects of Hibiscus sabdariffa extract powder and preventive treatment (diet) on the lipid profiles of patients with metabolic syndrome (MeSy). Phytomedicine, 17(7), 500-505.

46. Guzman-Geronimo, R.J., Alarcon-Zavaleta, T.M., Oliart-Ros, R.M., Meza-Alvarado, J.E., Herrera-Meza, S., Chavez-Servia, J.L. (2017). Blue maize extract improves blood presure, lipid profiles, and adipose tissue in high-sucrose diet-induced metabolic syndrome in rats. Journal of Medicinal Food, 20(2), 110-115.

47. Harakotr, B., Suriharn, B., Tangwongchai, R., Scott, M. P., Lertrat, K. (2014). Anthocyanins and antioxidant activity in coloured waxy corn at different maturation stages. Journal of Functional Foods, 9, 109-118.

48. He, J., Giusti, M. (2010). Anthocyanins: Natural colorants with health-promoting properties. Annual Review of Food Science and Technology, 1, 163-187.

49. He, J., Magnuson, B.A., Giusti, M.M. (2005). Analysis of anthocyanins in rat intestinal contents-impact of anthocyanin chemical structure on fecal excretion. Journal of Agricultural and Food Chemistry, 53(8), 2859-2866.

50. Hernández-Uribe, J.P., Agama-Acevedo, E., Islas-Hernández, J.J., Tovar, J., Bello-Pérez, L.A. (2007). Chemical composition and in vitro starch digestibility of pigmented corn tortilla. Journal of the Science of Food and Agriculture, 87(13), 2482-2487.

51. Herrera-Sotero, M.Y., Cruz-Hernández, C.D., Trujillo-Carretero, C., Rodríguez-Dorantes, M., García-Galindo, H.S., Chávez-Servia, J.L., Oliart-Ros, R.M., Guzmán-Gerónimo, R.I. (2017). Antioxidant and antiproliferative activity of blue corn and tortilla from native maize. Chemistry Central Journal, 11(1), art. no. 110.

52. Hong, S.H., Heo, J.I., Kim, J.H., Kwon, S.O., Yeo, K.M., Bakowska-Barczak, A.M., Kolodziejczyk, P., Ryu, O.H., Choi, M.K., Kang, Y.H., Lim, S.S., Suh, H.W., Huh, S.O., Lee, J.Y. (2013). Antidiabetic and beta cell-protection activities of purple corn anthocyanins. Biomolecules \& Therapeutics, 21 (4), 284-289.

53. Horbowicz, M., Kosson, R., Grzesiuk, A., Dębski, H. (2008). Anthocyanins of fruits and vegetables - their occurrence, analysis and role in human nutrition. Vegetable Crops Research Bulletin, $68,5-22$.

54. Hosoda, K., Miyaji, M., Matsuyama, H., Haga, S., Ishizaki, H., Nonaka, K. (2012). Effect of supplementation of purple pigment from anthocyanin-rich corn (Zea mays L.) on blood antioxidant activity and oxidation resistance in sheep. Livestock Science, 145(1-3), 266-270.

55. Hu, C.Y., Li, Q.L., Shen, X.F., Quan, S., Lin, H., Duan, L., Wang, Y.F., Luo, Q., Qu, G.R., Han, Q., Lu, Y., Zhang, D.B., Yuan, Z., Shi, J.X. (2016). Characterization of factors underlying the metabolic shifts in developing kernels of colored maize. Scientific Reports, 6, art. no. 35479.

56. Huang, B., Wang, Z., Park, J., Ryu, O., Choi, M., Lee, J.-Y., Kang, Y., Lim, S. (2015). Anti-diabetic effect of purple corn ex- tract on $\mathrm{C} 57 \mathrm{BL} / \mathrm{KsJ} \mathrm{db} / \mathrm{db}$ mice. Nutrition Research and Practice, 9(1), 22-29.

57. Intuyod, K., Priprem, A., Limphirat, W., Charoensuk, L., Pinlaor, P., Pairojkul, C., Lertrat, K., Pinlaor, S. (2014). Anti-inflammatory and anti-periductal fibrosis effects of an anthocyanin complex in Opisthorchis viverrini-infected hamsters. Food and Chemical Toxicology, 74, 206-215.

58. Jansen, G., Flamme, W. (2006). Coloured potatoes (Solanum Tuberosum L.) - Anthocyanin content and tuber quality. Genetic Resources and Crop Evolution, 53(7), 1321-1331.

59. Kallam, K., Appelhagen, I., Luo, J., Albert, N., Zhang, H.B., Deroles, S., Hill, L., Findlay, K., Andersen, O.M., Davies, K., Martin, C. (2017). Aromatic decoration determines the formation of anthocyanic vacuolar inclusions. Current Biology, 27(7), 945-957.

60. Kalt, W., Blumberg, J., McDonald, J., Vinqvist-Tymchuk, M., Fillmore, S., Graf, B., O'Leary, J., Milbury, P. (2008). Identification of anthocyanins in the liver, eye, and brain of blueberry-fed pigs. Journal of Agricultural and Food Chemistry, 56(3), 705-712.

61. Kang, M.-K., Lim, S.S., Lee, J.-Y., Yeo, K.M., Kang, Y.-H. (2013). Anthocyanin-rich purple corn extract inhibit diabetesassociated glomerular angiogenesis. PloS One, 8(11), art. no. e79823.

62. Kasote, D.M., Katyare, S.S., Hegde, M.V., Bae, H. (2015). Significance of antioxidant potential of plants and its relevance to therapeutic applications. International Journal of Biological Sciences, 11(8), 982-991.

63. Kay, C. (2006). Aspects of anthocyanin absorption, metabolism and pharmacokinetics in humans. Nutrition Research Reviews, 19(1), 137-146.

64. Kay, C.D., Mazza, G., Holub, B.J. (2005). Anthocyanins exist in the circulation primarily as metabolites in adult men. Journal of Nutrition, 135(11), 2582-2588.

65. Kongpichitchoke, T., Hsu, J.L., Huang, T.C. (2015). Number of hydroxyl groups on the B-ring of flavonoids affects their antioxidant activity and interaction with phorbol ester binding site of PKC $\delta$ C1B domain: in vitro and in silico studies. Journal of Agricultural and Food Chemistry, 63(18), 4580-4586.

66. Lago, C., Cassani, E., Zanzi, C., Landoni, M., Trovato, R., Pilu, R. (2014). Development and study of a maize cultivar rich in anthocyanins: coloured polenta, a new functional food. Plant Breeding, 133(2), 210-217.

67. Lago, C., Landoni, M., Cassani, E., Doria, E., Nielsen, E., Pilu, R. (2013). Study and characterization of a novel functional food: purple popcorn. Molecular Breeding, 31 (3), 575-585.

68. Langley, P.C., Pergolizzi, J.V., Taylor, R., Ridgway, C. (2015). Antioxidant and associated capacities of camu camu (Myrciaria dubia): a sistematic review. Journal of Alternative and Complementary Medicine, 21 (1), 8-14.

69. Levi, M.A.B., Scarminio, L.S., Poppi, R.J., Trevisan, M.G. (2004). Three-way chemometric method study and UV-Vis absorbance for the study of simultaneous degradation of anthocyanins in flowers of the Hibiscus rosa-sinensys species. Talanta, 62(2), 299-305.

70. Li, C.Y., Kim, H.W., Won, S.R., Min, H.K., Park, K.J., Park, J.Y., Ahn, M.S., Rhee, H.L. (2008). Corn husk as a potential source of anthocyanins. Journal of Agricultural and Food Chemistry, 56(23), 11413-11416. 
71. Li, J., Kang, M.-K., Kim, J.-K., Kim, J.-L., Kang, S.-W., Lim, S.S., Kang, Y.-H. (2012b). Purple corn anthocyanins retard diabetes-associated glomerulosclerosis in mesangial cells and $\mathrm{db} / \mathrm{db}$ mice. European Journal of Nutrition, 51 (8), 961-973.

72. Li, J., Lim, S., Lee, J.-Y., Kim, J.-K., Kang, S.-W., Kim, J.-L., Kang, Y-H. (2012a). Purple corn anthocyanins dampened highglucose-induced mesangial fibrosis and inflammation: possible renoprotective role in diabetic nephropathy. The Journal of Nutritional Biochemistry, 23(4), 320-331.

73. Li, Q., Somavat, P., Singh, V., Chatham, L., de Mejia, E.G. (2017). A comparative study of anthocyanin distribution in purple and blue corn coproducts from three conventional fractionation processes. Food Chemistry, 231, 332-339.

74. Li, T.C., Zhang, W., Yang, H.Y., Dong, Q., Ren, J., Fan, H.H., Zhang, X., Zhou, Y.B. (2019). Comparative transcriptome analysis reveals differentially expressed genes related to the tissuespecific accumulation of anthocyanins in pericarp and aleurone layer for maize. Scientific Reports, 9, art. no. 2485.

75. Li, X., Qian, X., Lü, X., Wang, X.H., Jia, N., Zhang, M.S., Ren, M.J. (2018). Upregulated structural and regulatory genes involved in anthocyanin biosynthesis for coloration of purple grains during the middle and late grain-filling stages. Plant Physiology and Biochemistry, 130, 235-247.

76. Limsitthichaikoon, S., Khampaenjiraroch, B., Damrongrungruang, T., Limphirat, W., Thapphasaraphong, S. Priprem, A. (2018). Topical oral wound healing potential of anthocyanin complex: animal and clinical studies. Therapeutic Delivery, 9(5), 359-374.

77. Liu, Y.X., Song, X., Zhang, D., Zhou, F., Wang, D., Wei, Y., Gao, F.Y., Xie, L.Y., Jia, G., Wu, W., Ji, B. (2012). Blueberry anthocyanins: protection against ageing and light-induced damage in retinal pigment. British Journal of Nutrition, 108(1), 16-27.

78. Lobo, V., Patil, A., Phatak, A., Chandra, N. (2010). Free radicals, antioxidants and functional foods: Impact on human health. Pharmacognosy Review, 4(8), 118-126.

79. Lopez-Martinez, L.Y., Oliart-Ros, R.M., Valerio-Alfaro, G., Lee, C.-H., Parkin, K.L., Garcia, H.S. (2009). Antioxidant activity, phenolic compounds and anthocyanins content of eighteen strains of Mexican maize. LWT - Food Science and Technology, 42(6), 1187-1192.

80. Luna-Vital, D.A., de Mejia, E.G. (2018). Anthocyanins from purple corn activate free fatty acid-receptor 1 and glucokinase enhancing in vitro insulin secretion and hepatic glucose uptake. PLoS One, 13(7), art. no. e0200449.

81. Mamani-Choquepata, R., Mamani-Quispe, P., Manchego-Rosado, L., Moreno-Loaiza, O., Paz-Aliaga, A. (2013). Dose effect of anthocyanins of three extracts of Zea Mays L. (purple corn) in the vasodilation of rat aortic rings. Revista Peruana de Medicina Experimental y Salud Publica, 30(4), 714-728 (in Spanish).

82. Manach, C., Williamson, G., Morand, C., Scalbert, A., Rémésy, C. (2005). Bioavailability and bioefficacy of polyphenols in humans. I. Review of 97 bioavailability studies. The American Journal of Clinical Nutrition, 81(1), 230S-242S.

83. Mazza, G., Brouillard, R. (1990). The mechanism of co-pigmentation of anthocyanins in aqueous solutions. Phytochemistry, 29(4), 1097-1102.

84. Mazza, G., Kay, C.D., Cottrell, T., Holub, B.J. (2002). Absorption of anthocyanins from blueberries and serum antioxidant status in human subjects. Journal of Agricultural and Food Chemistry, 50(26), 7731-7737.

85. McCord, J.M. (2000). The evolution of free radicals and oxidative stress. American Journal of Medicine, 108(8), 652-659.

86. McGhie, T., Walton, M. (2007). The bioavailability and absorption of anthocyanins: towards a better understanding. Molecular Nutrition \& Food Research, 51 (6), 702-713.

87. Mex-Alvarez, R., Garma-Quen, P., Bolivar-Fernandez, N., Guillen-Morales, M., Tut-Heredia, J. (2016). Influence of the maize varieties Zea mays L. of Campeche on the weight gain in mice. Revista Iberoamericana de Ciencias, 3(5), 106-113 (in Spanish; English abstract),

88. Mora-Rochin, S., Gaxiola-Cuevas, N., Gutierrez-Uribe, J.A., Milan-Carrillo, J., Milan-Noris, E.M., Reyes-Moreno, C., Serna-Saldivar, S.O., Cuevas-Rodriguez, E.O. (2016). Effect of traditional nixtamalization on anthocyanin content and profile in Mexican blue maize (Zea mays L.) landraces. LWT - Food Science and Technology, 68, 563-569.

89. Moreno-Loaiza, O., Paz-Aliaga, A. (2010). Vasodilator effect mediated by nitric oxide of the Zea mays L. (andean purple corn) hydroalcoholic extract in aortic rings of rat. Revista Peruana de Medicina Experimental y Salud Publica, 27(4), 527-531 (in Spanish; English abstract).

90. Mullen, W., Edwards, C.A., Crozier, A. (2006). Absorption, excretion and metabolite profiling of methyl-, glucuronyl-, glucosyl-and sulpho-conjugates of quercetin in human plasma and urine after ingestion of onions. British Journal of Nutrition, 96(1), 107-116.

91. Nabae, K., Hayashi, S.M., Kawabe, M., Ichihara, T., Hagiwara, A., Tamano, S., Tsushima Y., Uchida, K., Koda, T., Nakamura, M., Ogawa, K., Shirai, T. (2008). A 90-day oral toxicity study of purple corn color, a natural food colorant, in F344 rats. Food and Chemical Toxicology, 46(2), 774-780.

92. Navolokin, N.A., Polukonova, N.V., Maslyakova, G.N., Bucharskaya, A.B., Durnova, N.A. (2012). Effect of extracts of Gratiolla Officinalis and Zea Mays on the tumor and the morphology of the internal organs of rats with transplanted liver cancer. Russian Open Medical Journal, 1(2), 1-4.

93. Pandey, K.B., Rizvi, S.I. (2009). Plant polyphenols as dietary antioxidants in human health and disease. Oxidative Medicine and Cellular Longevity, 2(5), 270-278.

94. Pedreschi, R., Cisneros-Zevallos, L. (2007). Phenolic profiles of Andean purple corn (Zea mays L.). Food Chemistry, 100(3), 956-963.

95. Peixoto, H., Roxo, M., Krstin, S., Rohrig, T., Richling, E., Wink, M. (2016). An anthocyanin-rich extract of Açai (Euterpe precatoria Mart.) increases stress resistance and retards aging-related markers in Caenorhabditis elegans. Journal of Agriculture and Food Chemistry, 64(6), 1283-1290.

96. Petrov, V., Diniz, A.M., Cunha-Silva, L., Parola, A.J., Pina, F. (2013). Kinetic and thermodynamic study of 2'-hydroxy-8-methoxyflavylium. Reaction network interconverting flavylium cation and flavanone. RSC Advances, 3(27), 10786-10794.

97. Piperno, D.R., Ranere, A.J., Holst, I., Iriarte, J., Dickau, R. (2009). Starch grain and phytolith evidence for early ninth millennium BP maize from the Central Balsas River Valley, Mexico. Proceedings of the National Academy of Sciences of the United States of America, 106(13), 5019-5024. 
98. Prior, R.L. (2003). Fruits and vegetables in the prevention of cellular oxidative damage. The American Journal of Clinical Nutrition, 78(3), 570S-578S.

99. Ramirez-Tortosa, C., Andersen, Ø.M., Gardner, P.T., Morrice, P.C., Wood, S.G., Duthie, S.J., Collins, A.R, Duthie, G.G. (2001). Anthocyanin-rich extract decreases indices of lipid peroxidation and DNA damage in vitamin E-depleted rats. Free Radical Biology and Medicine, 31 (9), 1033-1037.

100. Ramos-Escudero, F., Muñoz, A.M., Alvarado-Ortíz, C., Alvarado, A., Yáñez, J.A. (2012). Purple corn (Zea mays L.) phenolic compounds profile and its assessment as an agent against oxidative stress in isolated mouse organs. Journal of Medicinal Food, 15(2), 206-215.

101. Revilla, P., Soengas, P., Malvar, R.A. (2018). Effects of antioxidant activity of black maize in corn borer larval survival and growth. Spanish Journal of Agricultural Research, 16(1), art. no. e1004.

102. Rice-Evans, C.A., Miller, N.J., Paganga, G. (1996). Structure-antioxidant activity relationships of flavonoids and phenolic acids. Free Radical Biology and Medicine, 20(7), 933-956.

103. Rice-Evans, C.A., Miller, N.J., Paganga, G. (1997). Antioxidant properties of phenolic compounds. Trends in Plant Science, 2(4), 152-159.

104. Rocchetti, G., Giuberti, G., Gallo, A., Bernardi, J., Marocco, A., Lucini, L. (2018). Effect of dietary polyphenols on the in vitro starch digestibility of pigmented maize varieties under cooking conditions. Food Research International, 108, 183-191.

105. Roh, K.-B., Kim, H., Shin, S., Kim, Y.-S., Lee, J.-A., Kim, M.O., Jung, E., Lee, J., Park, D. (2016). Anti-inflammatory effects of Zea mays L. husk extracts. BMC Complementary and Alternative Medicine, 16(1), art. no. 298.

106. Rojas-Molina, I., Gutierrez-Cortez, E., Palacios-Fonseca, A., Baños, L., Pons-Hernandez, J.L., Guzman-Maldonado, S.H., Pineda-Gomez, P., Rodriguez, M.E. (2007). Study of structural and thermal changes in endosperm of quality protein maize during nixtamalization process. Cereal Chemistry, 84(4), 304-312.

107. Sadilova, E., Stintzing, F.O., Carle, R. (2006). Anthocyanins, colour and antioxidant properties of eggplant (Solanum molongena L.) and violet pepper (Capsicum annum L.) peel extracts. Zeitschrift for Naturforschung C-A Journal of Biosciences, 61 (7-8), 527-535.

108. Salinas, M., Soto, H., Martinez, B., Gonzalez, H., Ortega, P. (1999). Análisis de antocianinas en maíces de grano azul y rojo provenientes de cuatro razas. Revista de Fitotecnia Mexicana, 22(2), 161-174 (in Spanish; English abstract).

109. Salinas-Moreno, Y., Cruz-Chavez, F., Diaz-Ortiz, S., Castillo-Gonzalez, F. (2012). Pigmented maize grains from Chiapas, physical characteristics, anthocyanin content and nutraceutical value. Revista de Fitotecnia Mexicana, 35(1), 33-41 (in Spanish; English abstract).

110. Salinas-Moreno, Y., Garcia-Salinas, C., Coutiño-Estrada, B., Vidal-Martinez, V. (2013). Content and type variability of anthocyanins in blue/purple colored grains of Mexican maize populations. Revista de Fitotecnia Mexicana, 36(3), 285-294 (in Spanish; English abstract).

111. Salinas-Moreno, Y., Rubio Hernández, D., Díaz Velázquez, A. (2005b). Extraction and use of pigments from maize grains (Zea mays L.) as colorants in yogurt. Archivos Latinoamericanos de Nutrición, 55(3), 293-298 (in Spanish; English abstract).
112. Salinas-Moreno, Y., Salas-Sanchez, G., Rubio-Hernandez, D., Ramos-Lobato, N. (2005a). Characterization of anthocyanins extracts from maize kernels. Journal of Chromatographic Science, 43(9), 483-487.

113. Sanchez J.J., Goodman, M.M., Stuber, C.W. (2000). Isozymatic and morphological diversity in the races of maize of Mexico. Economic Botany, 54(1), 43-59.

114. Serna-Saldivar, S., Gutierrez-Uribe, J., Mora-Rochin, S., Garcia-Lara, S. (2013). Nutraceutical potential of native maize and changes during traditional and extrusion processing. Revista de Fitotecnia Mexicana, 36(3), 295-304 (in Spanish; English abstract).

115. Sharma, M., Cortes-Cruz, M., Ahern, K.R., McMullen, M., Brutnell, T.P., Chopra, S. (2011). Identification of the Prl gene product completes the anthocyanin biosynthesis pathway of maize. Genetics, 188(1), 69-79.

116. Shen, L.Y., Petolino, J.F. (2006). Pigmented maize seed via tissue-specific expression of anthocyanin pathway gene transcription factors. Molecular Breeding, 18(1), 57-67.

117. Styles, E., Ceska, O. (1972). Flavonoid pigments in genetic strains of maize. Phytochemistry, 11(10), 3019-3021.

118. Suket, N., Srisook, E., Hrimpeng, K. (2014). Antimicrobial activity of the anthocyanins isolated from purple field corn (Zea mays L.) cob against Candida spp. Journal of Pharmacy and Biological Sciences, 9(4), 40-44.

119. Takeoka, G.R., Dao, L.T., Full, G.A., Wong, R.Y., Harden, L.A., Edwards, R.A., Berrios, J.D. (1997). Characterization of black bean (Phaseolus vulgaris L.) anthocyanins. Journal of Agricultural and Food Chemistry, 45(9), 3395-3400.

120. Talavéra, S., Felgines, C., Texier, O., Besson, C., Manach, C., Lamaison, J., Rémésy, C. (2004). Anthocyanins are efficiently absorbed from the small intestine in rats. Journal of Nutrition, 134(9), 2275-2279.

121. Thiraphatthanavong, P., Wattanathorn, J., Muchimapura, S., Thukham-Mee, W., Wannanon, P., Tong-un, T., Suriharn, B., Lertrat, K. (2014). Preventive effect of Zea mays L. (purple waxy corn) on experimental diabetic cataract. BioMed Research International, 2014, art. no. 507435.

122. Tian, Q.G., Giusti, M.M., Stoner, G.D., Schwartz, S.J. (2006). Urinary excretion of black raspberry (Rubus occidentalis) anthocyanins and their metabolites. Journal of Agricultural and Food Chemistry, 54(4), 1467-1472.

123. Tian, X.Z., Paengkoum, P., Paengkoum, S., Chumpawadee, S., Ban, C., Thongpea, S. (2019). Short communication: Purple corn (Zea mays L.) stover silage with abundant anthocyanins transferring anthocyanin composition to the milk and increasing antioxidant status of lactating dairy goats. Journal of Dairy Science, 102(1), 413-416.

124. Tiessen, A., Cubedo-Ruiz, E.A., Winkler, R. (2017). Improved representation of biological information by using correlation as distance function for heatmap cluster analysis. American Journal of Plant Sciences, 8(3), 502-516.

125. Toufektsian, M.C., de Longeril, M., Nagy, N., Salen, P., Donati, M.B., Giordano, L., Mock, H.P., Peterek, S., Matros, A., Petroni, K., Pilu, R., Rotilio, D., Tonelli, C., de Leiris, J., Bouchet, F., Martins, C. (2008). Chronic dietary intake of plant-derived anthocyanins protects the rat heart against ischemia-reperfusion injury. Journal of Nutrition, 138(4), 747-752. 
126. Tsuda, T. (2012). Dietary anthocyanin-rich plants: biochemical basis and recent progress in health benefits studies. Molecular Nutrition \& Food Research, 56(1), 159-170.

127. Tsuda, T., Horio, F., Osawa, T. (2000). The role of anthocyanins as an antioxidant under oxidative stress in rats. Biofactors, 13(1-4), 133-139.

128. Tsuda, T., Horio, F., Uchida, K., Aoki, H., Osawa, T. (2003). Dietary cyanidin 3-O- $\beta$-D-glucoside-rich purple corn color prevents obesity and ameliorates hyperglycemia in mice. Journal of Nutrition, 133(7), 2125-2130.

129. Urias-Lugo, D.A., Heredia, J.B., Muy-Rangel, M.D., Valdez-Torres, J.B., Serna-Saldivar, S.O., Gutierrez-Uribe, J.A. (2015b). Anthocyanins and phenolic acids of hybrid and native blue maize (Zea mays L.) extracts and their antiproliferative activity in mammary (MCF7), liver (HepG2), colon (Caco2 and HT29) and prostate (PC3) cancer cells. Plant Foods for Human Nutrition, 70(2), 193-199.

130. Urias-Lugo, D.A., Heredia, J.B., Serna-Saldivar, S.O., Muy-Rangel, M.D., Valdez-Torres, J.B. (2015a). Total phenolics, total anthocyanins and antioxidant capacity of native and elite blue maize hybrids (Zea mays L.). CyTA - Journal of Food, 13(3), 336-339.

131. Urias-Peraldi, M., Gutierrez-Uribe, J.A., Preciado-Ortiz, R.E., Cruz-Morales, A.S., Serna-Saldivar, S.O., Garcia-Lara, S. (2013). Nutraceutical profiles of improved blue maize (Zea mays) hybrids for subtropical regions. Field Crops Research, 141, 69-76.

132. Villasante, A., Patro, B., Chew, B., Becerra, M., Wacyk, J., Overturf, K., Powell, M.S, Hardy, R.W. (2015). Dietary intake of purple corn extract reduces fat body content and improves antioxidant capacity and $n-3$ polyunsaturated fatty acid profile in plasma of rainbow trout, Oncorhynchus mykiss. Journal of the World Aquaculture Society, 46(4), 381-394.

133. Wallace, T.C., Giusti, M.M. (2015). Anthocyanins. Advances in Nutrition, 6(5), 620-622.

134. Wang, D., Wei, X., Yan, X., Jin, T., Ling, A. (2010). Protocatechuic acid, a metabolite of anthocyanins, inhibits monocyte adhesion and reduces atherosclerosis in apolipoprotein E-deficient mice. Journal of Agricultural and Food Chemistry, 58(24), 12722-12728.

135. Wang, H., Cao, G.H., Prior, R.L. (1997). Oxygen radical absorbing capacity of anthocyanins. Journal of Agricultural and Food Chemistry, 45(2), 304-309.

136. Wang, H., Nair, M.G., Strasburg, G.M., Chang, Y.C., Booren, A.M., Gray, J.I., DeWitt, D.L. (1999). Antioxidant and antiinflammatory activities of anthocyanins and their aglycon, cyanidin, from tart cherries. Journal of Natural Products, 62 (2), 294-296.

137. Wang, L.S., Stoner, G.D. (2008). Anthocyanins and their role in cancer prevention. Cancer Letters, 269(2), SI, 281-290.

138. Wattanathorn, J., Thiraphatthanavong, P., Muchimapura, S., Thukhammee, W., Lertrat, K., Suriharn, B. (2015). The com- bined extract of Zingiber officinale and Zea mays (purple color) improves neuropathy, oxidative stress, and axon density in streptozotocin induced diabetic rats. Evidence-Based Complementary and Alternative Medicine, 2015, art. no. 301029.

139. Wu, T., Guo, X.Q., Zhang, M., Yang, L., Liu, R., Yin, J.J. (2017). Anthocyanins in black rice, soybean and purple corn increase fecal butyric acid and prevent liver inflammation in high fat diet-induced obese mice. Food \& Function, 8(9), 3178-3186.

140. Yang, M., Kooh, S.I., Song, W.O., Chun, O.K. (2011). Food matrix affecting anthocyanin bioavailability: Review. Current Medicinal Chemistry, 18, 291-300.

141. Yang, Z., Zhai, W. (2010). Identification and antioxidant activity of anthocyanins extracted from the seed and cob of purple corn (Zea mays L.). Innovative Food Science Emerging Technologies, $11(1), 169-176$.

142. Yonekura-Sakakibara, K., Fukushima, A., Nakabayashi, R., Hanada, K., Matsuda, F., Sugawara, S., Inoue, E., Kuromori, T., Ito, T., Shinozaki, K., Wangwattana, B., Yamazaki, M., Saito, K. (2012). Two glycosyltransferases involved in anthocyanin modification delineated by transcriptome independent component analysis in Arabidopsis thaliana. Plant Journal, 69(1), 154-167.

143. Zhang, Q., Luna-Vital, D., de Mejia, E.G. (2019). Anthocyanins from colored maize ameliorated the inflammatory paracrine interplay between macrophages and adipocytes through regulation of NF- $\mathrm{KB}$ and JNK-dependent MAPK pathways. Journal of Functional Foods, 54, 175-186.

144. Zhang, Z., Yang, L., Ye, H., Du, X.F., Gao, Z.M., Zhang, Z.-L. (2010). Effects of pigment extract from black glutinous corncob in a high-fat-fed mouse model of hyperlipidemia. European Food Research and Technology, 230(6), 943-946.

145. Zhang, Z., Zhou, B., Wang, H.H., Wang, F., Song, Y.L., Liu, S.N., Xi, S.H. (2014). Maize purple plant pigment protects against fluoride-induced oxidative damage of liver and kidney in rats. International Journal of Environmental Research and Public Health, 11(1), 1020-1033.

146. Zhao, C.L., Chen, Z.J., Bai, X.S., Ding, C., Long, T.J., Wei, F.G., Miao, K.R. (2014). Structure-activity relationships of anthocyanidin glycosylation. Molecular Diversity, 18(3), 687-700.

147. Zhao, X.Y., Zhang, C., Guigas, C., Ma, Y., Corrales, M., Tauscher, B., Hu, X.S. (2009). Composition, antimicrobial activity, and antiproliferative capacity of anthocyanin extracts of purple corn (Zea mays L.) from China. European Food Research and Technology, 228(5), 759-765.

148. Žilić, S., Serpen, A., Akıllıoğlu, G., Gökmen, V., Vančetović, J. (2012). Phenolic compounds, carotenoids, anthocyanins, and antioxidant capacity of colored maize (Zea mays L.) kernels. Journal of Agricultural and Food Chemistry, 60(5), 1224-1231.

Submitted: 23 May 2019. Revised: 19 July and 15 October 2019. Accepted: 22 October 2019. Published on-line: 17 December 2019. 